\title{
MARKETING AND HIGHER EDUCATION-CONDITION IN SERBIA
}

\author{
Saša Marković, Slavoljub Vujovićc ${ }^{2}$, Aleksandar Damnjanovićc ${ }^{3}$
}

\begin{abstract}
The inductive research approach is directed to testing of the hypothesis: about implementing marketing management, depending on the configuration properties of a successful education, and expressed with increased customer satisfaction in Serbia. The survey results confirm that the quality of service in higher education institutions in Serbia depends on the configuration properties of a successful education. Finally, it was confirmed that the success of marketing activities directly depends on the degree of customer satisfaction. One of the main specificities of higher education, even in comparison to other industries and service, is that the service provides a number of years and what is its value after successful completion of use, lifetime. Higher education institutions are in a unique position to build good relations with existing customers directly affected by the increase in the number of users in the future tense.
\end{abstract}

Key words: marketing, management, higher education institution

JEL: M31, M12, I23

\section{Introduction}

The Republic of Serbia has established a system of funding higher education institutions in which the amount of founds depends on the number of students enrolled. This is the reason that higher education institutions in Serbia are increasingly determining their work in accordance with the modern approach to the Science on business organization (Adcroft, Teckman, Willis 2010). The modern approach to education requires serious incorporate disciplines of management and marketing (Assael, 1992). Area of higher

1 Saša Marković, Professor of vocational studies, High school of vocational studies, Beogradska politehnika, Katarine Ambrozić 3, 11000 Belgrade, Serbia, Tel.: +381 65 8024464; Fax.: +38111 3809731, smarkovic@politehnika.edu.rs

2 Slavoljub Vujović, Senior research associate and professor of vocational studies, Beogradska poslovna skola-visoka skola strukovnih studija, Kraljice Marije 73, 11000 Belgrade, Serbia, Tel.: +3811130 42 300; Fax.: +381112424 069, kelovic1967@yahoo.com

3 Aleksandar Damnjanović Ph.D., Associate Professor, Faculty for Economics,,Dositej“ Belgrade „Dositej“, Nikole Pašića Square no. 7, 11000 Belgrade, Serbia, Phone: +381 64 0028 388, E-mail: $\underline{\text { adm.tfc@gmail.com }}$

EP 2017 (64) 4 (1635-1649) 
education institution is good example how management should insist on making a long term marketing strategy. Kotler and Keller insist on next definition (Barnes, 1993): „Marketing management can be considered as science and art of targeting the market, ability of winning and saving customers and giving them the superior qualities than the competition". Conclusion is that in higher education institutions entering the new students has the outstanding importance (keeping the continuity of new entries) and giving them wide range of apropriate values. In terms of marketing, for higher education institutions the most important goal is to become market-oriented. This involves fostering a greater degree of collaboration between internal departments, monitoring competitors and developing a focus on a wide range of institutional publics (Conway, Mackay, York, 1994). Simultanoeusly, the focus of higher education institutions is a configuration value as a key factor in communicating with potential service users.

According to Kotler and Fox, there are also definite stages in the evolution of marketing in higher education. The focus has moved from "marketing is unnecessary" to "marketing is promotion" to "marketing is positioning" to the stage where in some cases marketing is seen as part of strategic planning for higher education institutions (Ellis, 2005).

The business philosophy of marketing leads us on an integrated approach by all stakeholders, not just individuals and certain groups. Kotler and Armstrong (Foskett, 1998) identify four stages that strongly influence the evolution of organizations' marketing activities. These stages are referred to as production, sales, marketing and societal marketing. The exercise of this role requires a proactive approach to marketing that implies such thinking and operational approaches should provide efficient adaptable environment (Foxhall and Goldsmith 1998). An important feature of a proactive approach to the process of adaptation doesn't go subsequently, but in advance, therefore, a priori. It also points to the general importance of social marketing, which is not only used in material production, but, it could be said, in the whole system of life. The business-philosophical component of marketing refers us on special way of creation, entrepreneurship and realization of business activities, so then on specificity of mental and operational access to whole organization of life (Grey, 1991, p.231).

McCarthy and Perreault consider that marketing is process of planning, determining prices, promotion and distribution of ideas, goods and services in order to exchange that satisfies individual and corporative aims (Gwin, 1990).

Foxhall and Goldsmith consider that consumer orientation stems from an organization's adoption and implementation of the marketing mix (price, service, product, promotion, place, people, process, physical evidence), but adds that the adoption and implementation of the marketing concept has four major implications (Hayrinen-Alestalo and Peltola, 2006):

- "The success of any organization depends above all on the consumers and what they are willing to accept and pay.

- The organization must be aware of what the market wants, preferably well before production commences. 
- Consumer wants must be continually monitored and measured so that, through service product and market development, the organization keeps ahead of competitors.

- Top management must achieve the integration of all the components of the marketing strategy into a single strategic plan, based on knowledge of consumer behavior."

However, the rapid development of civilization results in continuous growth of requirements from potential users. According to Kotler (Hemsley-Brown and Oplatka 2010) and McCarthy and Perreault (Gwin, 1990), the marketing concept is based on four based principles: consumers' orientation or the target market, long-term maximization of profitability or another measure of long-term success, total organization effort, and social responsibility. Creating a marketing concept for any institution involves respecting the necessity of the introduction of continuous change: product and business organizations. Assael underlines the importance of the marketing concept by stating that the marketing concept embodies the view than an industry is a consumers' satisfying process, not a goods producing process (Ivanchevich, and other, 1994).

Assael (Ivanchevich, and other, 1994) and Trustrum (Kasper, 2002), agree that the basic idea of the marketing concept is to give the customers what they want. However, consumers are not always sure of their wants or what they are being offered, and are much more opened to persuasion than is commonly acknowledged by the marketing concept. This highlights the importance of a comprehensive study of user requirements. This paper was partly aimed at seeking solutions to higher education institutions so that they better meet their markets, but also to their marketing activities conducted in a more efficient manner.

\section{The task of marketing management in serbian higher education}

Previously mentioned allows to formulate the task of marketing management in higher education institutions: establishing an appropriate relationship with the target user groups so as to ensure a stable market position.

Miller, Erickson and Redman states the main reasons for the introduction and implementation of marketing in higher education (Kotler, 1979):

- "demographic trends,

- higher responsibility of educational institution in society, and

- increase number of institutions.

Barns (Barnes) list some other reasons (Kotler and Armstrong 1999):

- better communication between providers and users of educational service,

- creating positive institutional image,

- improvement of educational possibilities with aim to derive additional funds, and 
- better organizational efficiency and success of integration key issues of management.

Marketing in higher education institutions can achieve success if you recognize, and put the emphasis on certain properties. Rindfleish (Kohli and Jaworski 1990) believes that marketing is a process, not a campaign related to an event. Marketing concept is necessary to build a view of the situation, that is, the tendency of changes in the environment. The process of marketing in higher education institutions is pointed at „the needs, wants, and expectations of an organization's various customers or stakeholders" (Kohli and Jaworski 1990, p.234). Accomplishing this goal is possible only with cooperation of all employees: leadership, professorial corps and other staff. It is the continuity of Marketing Management, an indicator of a good customer service on rational channeling of available and potential resources. Marketing concept far exceeds the activity of selling, which basically has the property of purchasing transaction: „Marketing includes multiple phases of activities such as forecasting, product development, position assessment, market research, branding, creation of communication materials, and public relations that enhance the institution's long-term relationship with its "customers" or audience" (Kotler and Armstrong, 1999, p.238).

Organization of research needs (desired values of) users, taking into account the specifics of particular target groups, reduces risk, and thus the cost of implementation of marketing when using marketing instruments: „product/service, price, place, promotion, process, people and physical evidence, so, marketing-mix" (Kotler and Fox 1985). It is believed that the higher education institutions is very great importance of the product planning.

Market research services, education, promotion, performance of sales transactions, and raising funds from donors represent a form of communication with users. Marketing management of higher education institutions involves the establishment of appropriate business organization (in terms of structure and function). Foxhall and Goldsmith consider that the adoption and implementation of the marketing concept has four major implications (Hayrinen-Alestalo and Peltola, 2006, p.251):

- "- The success of any organization depends above all on the consumers and what they are willing to accept and pay.

- The organization must be aware of what the market wants, preferably well before production commences.

- Consumer wants must be continually monitored and measured so that, through service product and market development, the organization keeps ahead of competitors.

- Top management must achieve the integration of all the components of the marketing strategy into a single strategic plan, based on knowledge of consumer behavior." 
Marketing management recognizes current situation, providing positive results of current operations and the timely creation of the basics for survival in the long term.

\section{Hypotheses and research method}

The study of marketing management in higher education institutions assumes coverage of a number of factors, as it has been highlighted above. Taking appropriate measures that lead to the desired results requires management focus. Adequate answer to the question about the choice of focus hypothesis and its verification through the inductive research. It is very important to answer these questions: Is it even necessary to consider the concept of Marketng in higher education? Then, consider what and how should be done to improve the quality of services. Finally, to answer the question: Will these efforts really have the desired response - increased customer satisfaction? In that sense, set the following hypotheses:

- Higher education institutions in Serbia are implementing Marketing Management.

- Service quality in higher education institutions in Serbia depends on the configuration properties of a successful education.

- Results of marketing management in higher education institutions in Serbia are expressed with increased customer satisfaction.

When choosing a method of sampling (Kotler and Fox 1995) we was a basic set is defined the first. This was a population of colleges and universities in the territory of Serbia. Then, the method includes the frame definition, by determination the location of the contact unit. The sampling frame was formed from the list of higher education institutions, published by the Commission for Accreditation and Quality Assurance of the Ministry of Education of the Republic of Serbia. The method of quota sample was used, with the goal of the optimal selection of important characteristics for different subsets of the basic set. As this method is a combination of stratified and intentional sample, it is accessed through three stages. First, the certain basic set, then joined the determination of strata due to the expected $\sim$ heterogeneity characteristics measured at the end of a certain sample size. The total of 747 students, studying in higher education institutions and universities in eleven cities in Serbia, were included in the interview process.

In the empirical part of the paper is applied survey research techniques and instruments were questionnaires: for staff in higher education institutions and students. Students filled it anonymously, which increased their sincerity in expressing views and opinions. Since the intention was to examine their attitudes, opinions and interests, there is belief that the determination of these properties in the context of research topics best manifested through selected and specified research techniques, and instrument. Questionnaires for staff in higher education institutions were sent randomly to specific individuals. The authors' intention was to make the selection of employees according to certain criteria which are primarily related to their familiarity with developments in the institution where they are employed. Therefore, the questionnaires were sent to employees by prior arrangement and agreement. Despite the fact that the results 
obtained could do, they get their certificate and a comparative analysis using secondary data sources through a comparison with the results of the questionnaires received by the students.

Instrument designed for higher education institutions - employees, consisted of three major units that are separated by the specifics of individual research instrument (questionnaire). The first consisted of questions related to general data (total 15 questions). Second part of the instrument consisted of attitude scale, that is emerged as part of the questionnaire, in order to simplify the process of research to the respondents, Attitude scale pursued establishing the attitudes of respondents - employees compared to employees and users of educational services and general services in higher education institutions in which they work. The third and final section covers a questionnaire with 15 questions that are related to the educational process.

Instrument designed for students consisted also of three major units that are separated by the specifics of individual research instrument (questionnaire). The first consisted of questions relating to the general demographic and economic data (total of 9 questions). Second part of the instrument consisted of questions that were related to the attitudes of employees regarding relations with them (relationship and extracurricular services). Study of the attitudes of the respondents - students tended to establish attitudes of respondents in terms of satisfaction with the services provided by the staff employed in higher education institutions where they study, with emphasis on the part of the staff that makes direct contact with students. The third and final section covers a questionnaire with 10 questions that are related to education process ("the teaching").

\section{Results and discussion on marketing research in higher education in serbia}

Of the 65 surveyed of higher education institutions in Serbia, marketing activities are conducted in 48 institutions, or $73.8 \%$, while the 17 institutions, or $26.2 \%$, did not carry out marketing activities (Table 1).

Table 1. Does your institution relies on marketing activities?

\begin{tabular}{|l|l|l|l|l|l|}
\hline \multicolumn{2}{|l|}{ Valid } & Frequency & Percent & Valid Percent & Cumulative Percent \\
\hline \multirow{3}{*}{} & Yes & 48 & 73,8 & 73,8 & 73,8 \\
\cline { 2 - 6 } & No & 17 & 26,2 & 26,2 & 100 \\
\cline { 2 - 6 } & Total & 65 & 100 & 100 & \\
\hline
\end{tabular}

Source: research by the author

Although the number of higher education institutions that conduct marketing activities is relatively high, they are mainly related to promotional activities. 
Table 2. Average rating institutions towards the implementation of marketing

\begin{tabular}{|l|l|l|l|l|l|l|}
\hline & $\begin{array}{l}\text { Implementation of } \\
\text { marketing skills }\end{array}$ & $\begin{array}{l}\text { T h e } \\
\text { a v e r a g e } \\
\text { score }\end{array}$ & SD & T & df & importance \\
\cline { 2 - 7 } & AS & 2,92 & 0,679 & $-25,04$ & 747 & 0 \\
\hline \multirow{2}{*}{$\begin{array}{l}\text { Rating of your } \\
\text { institution }\end{array}$} & Yes & No & 4,71 & 0,721 & & \\
\cline { 2 - 7 }
\end{tabular}

Source: research by the author

The table shows that a significantly higher score gives students to a higher education institutions that conducts marketing activities.

Tabela 3. Average rating institutions by ownership structure of the institutions

\begin{tabular}{|l|l|l|l|l|l|l|}
\hline & $\begin{array}{l}\text { E d u c a t i o n } \\
\text { sector }\end{array}$ & AS & SD & T & df & importance \\
\hline $\begin{array}{l}\text { Rating of your } \\
\text { institution }\end{array}$ & state & 3,01 &, 671 & \multirow{2}{*}{$-21,17$} & 747 &, 000 \\
\cline { 2 - 4 } & private & 4,77 &, 623 & & \\
\hline
\end{tabular}

Source: research by the author

From this table it can be seen that the average score of private higher education institutions is significantly higher than the state's higher education institutions.

Tabela 4. The average quality score of exposure of teachers to the ownership structure of higher education institutions

\begin{tabular}{|l|l|l|l|l|l|l|}
\hline & $\begin{array}{l}\text { Department of } \\
\text { Education }\end{array}$ & AS & SD & T & df & importance \\
\hline $\begin{array}{l}\text { How do you rate the } \\
\text { quality of teacher } \\
\text { presentations? }\end{array}$ & State & 3,20 &, 633 & \multirow{2}{*}{$-21,50$} & 747 &, 000 \\
\cline { 2 - 4 } & Private & 4,12 &, 698 & $-21,50$ & \\
\hline
\end{tabular}

Source: research by the author

And with this element, students of private higher education institutions, they gave higher average grade their teachers than state institutions.

Table 5. Correlation of quality of presentations and teachers motivation to work

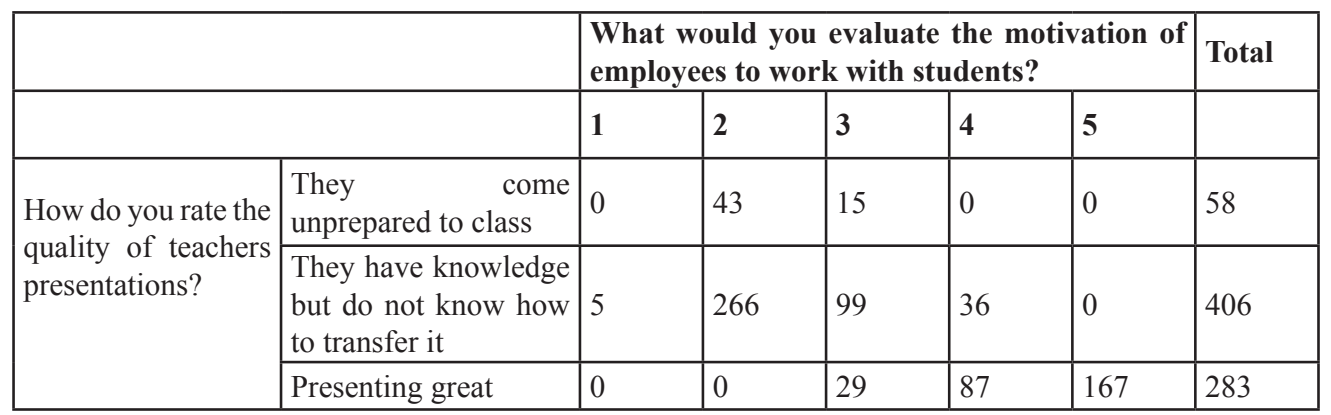




\begin{tabular}{|l|l|l|l|l|l|l|}
\hline Total & 5 & 309 & 143 & 123 & 167 & 747 \\
\hline
\end{tabular}

Source: research by the author

Chi-Square Tests

\begin{tabular}{|l|l|l|l|}
\hline & Value & df & importance \\
\hline Pearson Chi-Square & $339,202(\mathrm{a})$ & 8 &, 000 \\
\hline
\end{tabular}

Directional Measures

\begin{tabular}{|c|c|c|}
\hline & & Value \\
\hline Nominal by Interval & Eta &, 808 \\
\hline
\end{tabular}

As can be seen, there is a high correlation between the motivation of employees to work with the students and the quality of presentation. In following table we list the evaluation of the performance of student services given by students.

Table 6. The average score of student work services to the ownership structure of higher education institutions

\begin{tabular}{|l|l|l|l|l|l|l|}
\hline & $\begin{array}{l}\text { sector } \\
\text { education }\end{array}$ & AS & SD & T & df & Importance \\
\cline { 1 - 5 } $\begin{array}{l}\text { How do you rate } \\
\text { the work of Student } \\
\text { Services }\end{array}$ & State & 2,88 &, 659 & \multirow{2}{*}{$-31,88$} & 744 &, 000 \\
\cline { 2 - 5 }
\end{tabular}

Source: research by the author

Student services in private institutions of higher education have significantly higher grade point average. That primarily contributes to the growing number of employees in students services and more time working with students in private higher education institutions.

Table 7. The rating of service environment according to the ownership structure of higher education institutions

\begin{tabular}{|c|c|c|c|c|c|c|}
\hline & \begin{tabular}{|l|} 
Department of \\
Education
\end{tabular} & AS & SD & $\mathbf{T}$ & df & importance \\
\hline \multirow{2}{*}{$\begin{array}{l}\text { How do you rate } \\
\text { ambient of your } \\
\text { institution? }\end{array}$} & State & 2,80 &, 756 & \multirow{2}{*}{$-25,30$} & \multirow{2}{*}{747} & \multirow{2}{*}{,000 } \\
\hline & Private & 4,76 &, 738 & & & \\
\hline
\end{tabular}

Source: research by the author

There was a statistically significant difference among the students of the state and the private sector in terms of satisfaction with buildings and rooms for classes. A lot of students are satisfied with the private sector. 
Table 8. Correlation of quality of exposure for teachers and general evaluation of institutions. Count Cross tabulation

\begin{tabular}{|c|c|c|c|c|c|c|c|}
\hline & & \multicolumn{5}{|c|}{\begin{tabular}{|l|} 
How would you rate the average score \\
of the institution where you study?
\end{tabular}} & \multirow[t]{2}{*}{ Total } \\
\hline & & 1 & 2 & 3 & 4 & 5 & \\
\hline \multirow[t]{3}{*}{$\begin{array}{l}\text { How do you rate the } \\
\text { quality of teacher's } \\
\text { presentations? }\end{array}$} & $\begin{array}{l}\text { They come unprepared to } \\
\text { class }\end{array}$ & 0 & 36 & 10 & 0 & 0 & 46 \\
\hline & $\begin{array}{l}\text { They know a lot, but } \\
\text { they do not know how to } \\
\text { transfer knowledge }\end{array}$ & 5 & 253 & 112 & 62 & 0 & 432 \\
\hline & $\begin{array}{l}\text { Clearly } \\
\text { u n d e r s t a n d a b l y } \\
\text { presenting }\end{array}$ & 0 & 0 & 23 & 81 & 165 & 269 \\
\hline \multicolumn{2}{|l|}{ Total } & 5 & 289 & 145 & 143 & 165 & 747 \\
\hline
\end{tabular}

Source: research by the author

Chi-Square Tests

\begin{tabular}{|l|l|l|l|}
\hline & Value & df & importance \\
\hline Pearson Chi-Square & $339,202(a)$ & 8 &, 000 \\
\hline
\end{tabular}

Directional Measures

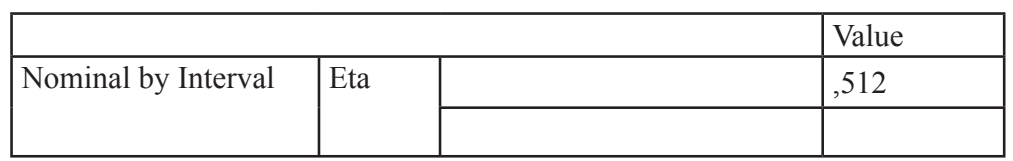

As can be seen, between the mode of presentation for teachers and general evaluation of the institution, there is a statistically significant positive correlation. Although the students evaluated the overall motivation of the staff, the staffs in the higher education institutions district are numerous and are the main carriers of educational activities. For this reason, we make a correlation between the quality of presentations of teachers and their willingness to work with students.

Tabela 9. Correlation of performance assessment of student services and general evaluation of institutions

\begin{tabular}{|l|l|l|}
\hline \multicolumn{2}{|l|}{} & $\begin{array}{l}\text { How do you evaluate work of } \\
\text { student's service? }\end{array}$ \\
\hline & Pearson Correlation &, $844(* *)$ \\
\hline & importance &, 000 \\
\hline & N & 747 \\
\hline
\end{tabular}

** Correlation is significant at the 0.01 level (2-tailed).

EP 2017 (64) 4 (1635-1649) 
There was a statistically significant positive correlation, it can be concluded that the work of student services greatly affect the overall evaluation of the institution that occupies an important place in the attitudes and perceptions of the educational services throughout the facility.

Table 10. Correlation between service atmosphere and general evaluation of institutions

\begin{tabular}{|l|l|l|}
\hline \multicolumn{2}{|l|}{} & $\begin{array}{l}\text { Average rate of your } \\
\text { institution? }\end{array}$ \\
\hline $\begin{array}{l}\text { How do you rate the layout } \\
\text { and arrangement of buildings } \\
\text { and classes? }\end{array}$ & Pearson Correlation &, $885(* *)$ \\
\hline & importance &, 000 \\
\hline & $\mathrm{N}$ & 747 \\
\hline
\end{tabular}

** Correlation is significant at the 0.01 level (2-tailed).

As can be seen, there is a statistically significant positive correlation between the service atmosphere and general evaluation of the institution. It is interesting to note that correlation between average grades and possible recommendations to the institution in which is studying.

Table 11. Correlation between average grades and possible recommendations to the institution in which is studying

\begin{tabular}{|l|l|l|l|l|}
\hline \multirow{2}{*}{$\begin{array}{l}\text { How would you rate the average } \\
\text { score of your institution? }\end{array}$} & \multicolumn{2}{|l|}{$\begin{array}{l}\text { Would you recommend } \\
\text { your institution? }\end{array}$} & \multirow{2}{*}{ Total } \\
\cline { 2 - 5 } & yes & No & \\
\hline \multirow{3}{*}{} & 1 & 6 & 12 & 18 \\
\hline & 2 & 5 & 67 & 72 \\
\hline 3 & 96 & 183 & 279 \\
\hline 4 & 193 & 8 & 201 \\
\hline 5 & 177 & 0 & 177 \\
\hline Total & 477 & 270 & 747 \\
\hline
\end{tabular}

Source: research by the author

Based on our research, it has been a statistically significant correlation between the three elements (ways of providing services, employees and the service ambient) and general evaluation of higher education institutions, which reflects the degree of satisfaction of users of educational services.

\section{Discussion of results}

Dispersed structure of values makes it difficult to measuring the success of higher education institutions. The criterion of high profits, of course, is important, but not enough in business of education. Success can be measured by the structure and the number of scientific papers and research projects, the achievement level of the 
students, the quality of teaching and professorial corps, public reputation, and so on. Then Marketing management should ensure a balance of effort in creating value for customers (eg: too many students require increased involvement of teachers, thereby negatively affecting their scientific and research paperworks).

From the (Table 1,2) above it can be seen that there is a higher level of customer satisfaction education services (students) who are studying in higher education institutions in Serbia, that are implementing the marketing activities and the level of satisfaction with smaller institutions that do not carry out marketing activities. Research confirms the first hypothesis. Therefore, for their survival in the market, it is essential that higher education institutions adopt and implement marketing concept.

Proving the second hypothesis required strong determination. It was determined the correlation between the degree of satisfaction of education services (students) and the three elements of the model servuqtion: ways of providing knowledge transfer (services), employees and service environment. (Termin Servuqtion means SERVICES and QUALITY. Model of Servuqtion aims to show the effects of four factors on the buyer/user services. Three factors are visible to users: environment, employees and other users, or others, and one is invisible - organization and management.) In this case, the method of providing services is related to the quality of teachers and exposure to the work of student services.

Quality of teachers in private and public institutions of higher education is perceived positively, as measured by student evaluations (Table 4). This result was confirmed by a significant positive correlation between the quality of the transfer of knowledge and motivation of teachers (Table 5). It is noted that the work of student services of private higher education institutions rated as excellent (4.82), compared to a state-owned institutions (2.88), ie., a weak evaluation of three (Table 5). And the third element, landscaping, the environment in which services are provided higher education (Table 6) shows that the institution of private property invest significantly more effort in ensuring appropriate working conditions for students and teachers. The willingness of students to recommend higher education institution (where i study) is accepted as the assessment criteria of success marketing activities. The survey results (Table 11) confirm the second hypothesis - that the quality of service in higher education institutions in Serbia depends on the configuration properties of a successful education.

Finally, the third hypothesis (that the results of marketing management in higher education institutions are expressing increased customer satisfaction) is confirmed in results of study (Table 9-11). The high degree of positive correlation characteristics of services with a general assessment of higher education institutions in Serbia shows that the success of marketing activities directly dependent on the degree of customer satisfaction.

Also, private higher education institutions have a significantly higher average grade from the state. Also, it can be seen that students give higher rating of the institution in which they study, are more likely to recommend their institution to potential students. Rating is an expression of satisfaction with the institution where the student is studying. 
If the institutions are more efficient and better satisfy the expectations and needs of its customers, it also reviews user to establish higher rates. Since that meeting the expectations and efficiently meeting the user's needs of educational services is one of the main objectives of marketing in higher education institutions, from the above it can be concluded that there is a need for acceptance and implementation of marketing.

According to Rindfleish, this forces higher education institutions to increasingly focus on marketing techniques used by profit organizations [14]. According to Paulsen [20], higher education institutions, in order to remain competitive, will have to use a marketing framework consisting of the following: (1) establish its image or market position; (2) identify competition; (3) determine the needs of the various market segments; and (4) develop a marketing plan for promoting their educational services. One of the key issues to the successful development of a marketing strategy is to determine which factor students consider when they have to make a decision on which institution to attend.

\section{Conclusion}

Given the length of use of educational services (three years and more), creating satisfied customers is a continuous process which is the primary task of the students regularly enrolled the next year of study, graduate and possibly continue their education through the master's and doctoral studies and after completing of the study continued cooperation with the institution where they have studied. In addition, users will be satisfied with oral spread a positive image of the institution in which they study, the potential beneficiaries of educational services. Otherwise, if the users dissatisfaction occurs, usually comes to withdrawing from the study and dissemination of the negative image of the institution.

Higher education institutions are service organizations that provide educational services to users. One of the main specificities of higher education, even in comparison to other service and industries, is that the service provides a number of years and what is its value after successful completion of use, lifetime. On satisfaction of educational services is influenced by many factors, but in most of them the dominant role of man - one who provides the service. The survey results should serve as a basis or ideas for the development of internal marketing, which should enable the recruitment, selection, training, motivation and retention of employees and encourage the best individuals. Higher education institutions are in a unique position to build good relations with existing customers directly affected by the increase in the number of users in the future tense. The advantages of this approach are multiple: increase the satisfaction of existing customers and at relatively low costs shall be the promotion of higher education and to the sources of information that has the most confidence.

Justification of determining the marketing concept, and then the success of the implementation of marketing activities assumes a complex process of inductive research. Since the results of marketing activity are intangible it involves the use of indirect criteria. In this paper, it was the accepted criterion of customer satisfaction students in higher education institutions. Thereby, the measurement of satisfaction of 
users according to different parameters tested, according to defined the hypothesis set.

Therefore, future development and application of marketing in higher education in Serbia should be directed to: the satisfaction of increased needs and requirements of educational services; effective links between education and the labor market, increasing attention to improving the quality of the overall service of the institution, the development and implementation of new forms of education, development of more effective communication with the relevant environmental factors, user involvement in the assessment of the results of the educational process in order to increase their satisfaction and reduce dropout rates and the creation of partnerships between higher education institutions and their customers.

\section{Acknowledgements}

The results of herein presented research were achieved within the scientific projects of the Ministry of Education, Science and Technological Development of the Republic of Serbia EE18031 and TR35030.

\section{References}

1. Adcroft, A., Teckman, J., Willis, R., (2010). "Is higher education in the UK becoming more competitive?", International Journal of Public Sector Management, Vol. 23 Iss: 6, pp. 578-588.

2. Assael, H., (1992). Consumer Behaviour and Marketing Action, Foutrh Edition, PWS-KENT Publishing Company, Boston.

3. Barnes, C., (1993). Practical Marketing for Schools, Oxford, Blackwell Publisher.

4. Conway, T., Mackay, S., York, D.,(1994). „Strategic planning in higher education: Who are the Customers?", International Journal of Educational Management, Vol 8 No. 6, pp 29-36 (35).

5. Ellis, P.D., (2005). „Market orientation and marketing practice in a developing economy“, European Journal of Marketing, Volume 39, Issue 5/6, pp. 629-645.

6. Foskett, N.H., (1998). „Schools and Marketization - Cultural Challenges and Respons“", Educational Management and Administration, Vol. 26, No. 2, rr. 201.

7. Foxhall, G.R., Goldsmith, R.E., (1998). Consumer Pshychology for marketing, Routledge.

8. Gray, L., (1991)., Marketing Education, Open University Press, Milton Keyns, pp 231.

9. Gwin, J.M., (1990). „Constituent Analysis: A Paradigm for Marketing Effectiveness in the Non-Profit Organisations“, European Journal of Marketing, Vol. 24, Issue 7.

10. Hayrinen-Alestalo, M., Peltola, U., ,The Problem of a Market Oriented University“،, Higher Education, Vol. 52, No. 2 (Sep. 2006), pp. 251-281. 
11. Hemsley-Brown, J., Oplatka, I., (2010). „Market orientation in uneiversities: A comparative study of two national higher education systems", International Journal of Educational Management, Vol. 24, Iss: 3, pp. 204-220.

12. Ivanchevich, J.M., Lorenzi, P., Skinner, S.J., Crosby, P.B., (1994). ManagementQuality and Competitiveness, Irwin.

13. Kasper, H., (2002). „Culture and leadership in market oriented service organizations“, European Journal of Marketing, Vol. 36 No. 9/10, pp 1047-1057.

14. Kohli, A.K., Jaworski, B.J., (1990). „Market Orientation: The construct, research proposition, and managerial implications“", Journal of Marketing, Vol. 54, No. 2, (Apr 1990), pp 1-18.

15. Kotler, P., Keller, K. L.: Marketing management, Pearson Education, Inc., Upper Sadlle River, New Jersey

16. Kotler, P., (1979). „Strategies for Introducing Marketing into Nonprofit Organizations“, The Journal of Marketing, Vol. 43, No. 1 (Jan., 1979), pp. 37-44.

17. Kotler, Ph., Armstrong, G., (1999). Principles of Marketing, Eight Edition, Prentice Hall International Inc., A Simon \& Schuster Company.

18. Kotler, Ph., Fox, K.F.A., (1985). Strategic Marketing for Educational Institutions, Prentice Hall Inc., New Jersey.

19. Kotler, Ph., Fox, K.F.A., (1995). Strategic Marketing for educational institutions, Englewood Cliffs, Prentice Hall.

20. Kotler, Ph., Upravljanje marketingom - analiza, planiranje, primena i kontrola, deveto izdanje, MATE, Zagreb.

21. Lovelock, C.H., (1996). Services Marketing, 3rd Edition, Prentice Hall College Div.

22. Mason, K.J., Harris, L.C., (2006). „Market orientation emphases: an exploration of macro, meso and micro drivers“, Marketing Intelligence and Planning, Vol 24 No. 6, pp. 552-571.

23. McCarthy, E.J., Perreault, W.D. Jr., (1993). Basic Marketing: A Global-Managerial Approach, Eleventh Edition, Irwin, pp 8.

24. Miller, T.R., Munoz-Erickson, T., Redman, C., (2011). „Transforming knowledge for sustainability: towards adaptive academic institutions", International Journal of Sustainability in Higher Education, Volume 12, Issue 2, pp 178.

25. Mullins, J.W., (2004). Marketing management, Irwin.

26. Paulsen, M.B., (1990). „College Choice: Understanding student enrolment behaviour", Higher Education Report, No. 6., The George Washington University, pp 55.

27. Peter, J.P., Donnelly, J.H., (1991). Marketing management: Knowledge and Skills, Third Edition, Irwin.

28. Pride, W.M., Ferrel, O.C., (1991). Marketing: Concepts and Strategies, Seventh edition, Houghton Mifflin Company, Boston. 
29. Rindfleisch, J.M., (2003), „Segment Profiling: reducing strategic risk in higher education managements“, Journal of Higher Education Policy and Management, 25(2), pp 148.

30. Stevovic, S., Miloradovic, M., Stevovic, I., (2014-a). Management of Environmental Quality and Kostolac Mine Areas Natural Resources Usage, Management of Environmental Quality: An International Journal, Vol 25-3, pp 473 - 488, www. emeraldinsight.com

31. Stevovic, S., Milosevic, H., Stevovic, I., Hadrovic, S., (2014-b). Sustainable management of water resources in Prokletije region, Industry, vol. 42, no. 1, pp 131 - 146, www.ecinst.org.rs/industrija

32. Trustrum, L.B., (1989). „Marketing: Concept and Function“, European Journal of Marketing, Vol. 23, Iss:3, pp 48.

\title{
MARKETING I VISOKO OBRAZOVANjE-STANJE U SRBIJI
}

\author{
Saša Markovićc ${ }^{4}$ Slavoljub Vujovićc ${ }^{5}$ Aleksandar Damnjanovićc
}

\begin{abstract}
Apstrakt
Smanjena ulaganja države (u javnom sektoru) u obrazovanju ili samostalnom finansiranju (u privatnom sektoru), porast broja studenata i konkurenata, negativni demografski $i$ ekonomski trendovi u Srbiji, naglašavaju neophodnost primene marketinga, izbor adekvatne marketing filozofije i sistemski pristup rešavanju problema. Učenici koji se upisuju na visokoškolske ustanove $i$ njihovi roditelji koji finansiraju studiranje, imaju relativno malo informacija o kvalitetu obrazovanja koje im određena ustanova pruža, kao i mogućnostima zapošljavanja nakon njenog završetka. Stoga je neophodno da se uspostavi komunikacija između davaoca usluga i korisnika i to sadašnjih, ali i potencijalnih.

Ključni preduslovi za razvoj uspešne marketing strategije se odnose na izbor ciljnog tržišta i koordinaciju instrumenata marketing miksa.
\end{abstract}

Ključne reči: marketing, visokoškolske ustanove, Srbija.

4 Saša Marković, Profesor strukovnih studija, Beogradska politehnika, Katarine Ambrozić 3, 11000, Beograd, Srbija, Tel..: +38111 3809731, smarkovic@,politehnika.edu.rs

5 Slavoljub Vujović, Viši naučni saradnik i profesor strukovnih studija, BPŠ, Kraljice Marije 73, 11000 Beograd, Srbija, Tel..: +38111 2424 069, kelovic1967@yahoo.com

6 Aleksandar Damnjanović, Vanredni profesor, Visoka škola akademskih studija „Dositej“, Trg Nikole Pašića no. 7, 11000 Belgrade, Srbija, Telefon: +381 640028 388, adm.tfc@gmail.com

EP 2017 (64) 4 (1635-1649) 
ECONOMICS OF

AGRICULTURE

\section{CONTENT}

1. Adriana Radosavac, Desimir Knežević

ECONOMIC IMPORTANCE OF USE

OF PESTICIDES IN WHEAT PRODUCTION . . . . . . . . . . . 1323

2. Berhe Gebregewergs, Muuz Hadush

DOES CLIMATE CHANGE AFFECT PRICE OF VEGETABLES:

EVIDENCE FROM TIGRAI, NORTHERN MOST ETHIOPIA. . . . .1335

3. Grujica Vico, Aleksandra Govedarica-Lučić, Zoran Rajić, Radomir Bodiroga, Ivan Mičić, Silvija Zec Sambol, Marija Mičić

MULTI ATTRIBUTE ASSESSMENT APPROACH

IN VEGETABLE PRODUCTION . . . . . . . . . . . . . . 1355

4. Igor Trandafilović, Vesna Conić, Aleksandra Blagojević

IMPACT OF DEMOGRAPHIC FACTORS ON

ENVIRONMENTALLY CONSCIOUS PURCHASE BEHAVIOUR. . .1365

5. Imre Milán Harcsa

STUDY ON THE POTENTIAL OF SUBCONTRACT

PALINKA DISTILLATION . . . . . . . . . . . . . . 1379

6. Jelena Andrašić, Vera Mirović, Nada Milenković, Branimir Kalaš, Miloš Pjanić

IMPACT OF TAKEOVER PROCESS ON EMPLOYEES -

EVIDENCE FROM FOOD, RETAIL AND FINANCIAL SECTOR . . .1393

7. Jelena Birovljev, Danilo Đokić, Bojan Matkovski, Žana Kleut

ECONOMIC PERFORMANCES OF AGRICULTURE

OF CEFTA AND FORMER CEFTA COUNTRIES . . . . . . . . . . 1413

8. Jelena Marković, Svetlana Stevović

SUSTAINABILITY OF CHEMICAL SOIL QUALITY

IN SOUTHERN MORAVA RIVER VALLEY

IN CORELLATION WITH THE FLOODING $\ldots \ldots \ldots \ldots \ldots$ 
9. Mile Peševski, Zoran Milovančević

THE CHANGES IN THE USAGE OF AGRICULTURAL LAND

IN EASTERN REGION OF REPUBLIC OF MACEDONIA

BETWEEN $1991-2030 \ldots \ldots$. . . . . . . . . . . . . . . . . . . . . . .

10. Odjuvwuederhie Emmanuel Inoni, 'Oraye Dicta Ogisi, Felix Odemero Achoja

PROFITABILITY AND TECHNICAL EFFICIENCY IN HOMESTEAD

CATFISH PRODUCTION IN DELTA STATE, NIGERIA . . . . . . . 1449

11. Olja Munitlak - Ivanović, Jovan Zubović, Petar Mitić

RELATIONSHIP BETWEEN SUSTAINABLE DEVELOPMENT AND

GREEN ECONOMY - EMPHASIS ON GREEN FINANCE

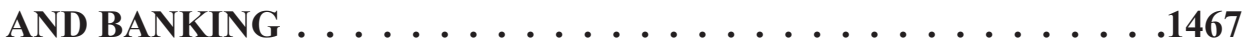

12. Petar Munćan, Dragica Božić

FARM SIZE AS A FACTOR OF EMLOYMENT AND INCOME

OF MEMBERS OF FAMILY FARMS . . . . . . . . . . . . . 1483

13. Rade Popović, Mira Kovljenić

EFFICIENCY OF WHEAT PRODUCTION ON FARMS

IN THE REPUBLIC OF SERBIA . . . . . . . . . . . . . . . . . . . . . . . . .

14. Radovan Damnjanović, Snežana Krstić, Milena Knežević, Svetislav Stanković,

Dejan Jeremić

THE DISCRIMINANT ANALYSIS APPLIED TO THE

DIFFERENTIATION OF SOIL TYPES . . . . . . . . . . . . 1513

15. Slavica Otović, Dunja Demirović, Kristina Košić, Aleksandra Vujko

FOSTERING ENTERPRENUERSHIP AT HIGH SCHOOLS:

A CASE OF RURAL AREAS IN VOJVODINA (SERBIA) . . . . . . .1523

16. Vladimir Ilić, Ivan Bauer, Anastazija Tanja Đelić, Aleksandar Nešković

INSTITUTIONAL SUPPORT FOR STRENGTHENING

ENTREPRENEURSHIP IN AGRICULTURAL PRODUCTION

OF THE REPUBLIC OF SERBIA . . . . . . . . . . . . . . . . . . . . . . . .

17. Boro Krstić, Zorica Vasiljević, Miroslav Nedeljković

INSURANCE CONTRACT AS THE BASIS FOR THE SAFETY OF

AGRICULTURAL PRODUCERS IN THE REPUBLIC OF SRPSKA • . 1555

18. Dejan Sekulić, Aleksandar Petrović, Vladimir Dimitrijević

WHO ARE WINE TOURISTS? AN EMPIRICAL INVESTIGATION

OF SEGMENTS IN SERBIAN WINE TOURISM . . . . . . . . . . . . . 
19. Milan Beslać, Ćorić Goran

FINANCIAL AND PRODUCTION ASPECTS OF GENETICALLY MODIFIED ORGANISMS $\ldots \ldots \ldots \ldots \ldots \ldots \ldots \ldots \ldots$

20. Mlađan Maksimović, Darjan Karabašević, Miodrag Brzaković, Pavle Brzaković THE EFFECTS RESULTING FROM THE APPLICATION OF THE CONCEPT OF THE SUSTAINABLE DEVELOPMENT OF RURAL TOURISM ON STARA PLANINA . . . . . . . . . . . . . . . .1595

21. Vesna Popović, Predrag Vuković, Milivoje Ćosić FOOD SAFETY AND QUALITY POLICY IN THE REPUBLIC OF SERBIA . . . . . . . . . . . . . . . . 1607

22. Radovan Pejanović, Danica Glavaš-Trbić, Mirela Tomaš-Simin PROBLEMS OF AGRICULTURAL AND RURAL DEVELOPMENT IN SERBIA AND NECESSITY OF NEW AGRICULTURAL POLICY . . . .1619

23. Saša Marković, Slavoljub Vujović, Aleksandar Damnjanović MARKETING AND HIGHER EDUCATION CONDITION IN SERBIA . . . . . . . . . . . . . . . . 1635

24. Semir Vehapi, Marina Milanović THE EFFECT OF MARKET ORIENTATION ON BUSINESS PERFORMANCE OF SERBIAN ORGANIC PRODUCERS . . . . . 1651

25. Suad Bećirović, Šemsudin Plojović, Enis Ujkanović, Senadin Plojović CHALLENGES AT STARTING AN AGRIBUSINESS IN THE HILLY MOUNTAINOUS REGIONS OF SOUTHWEST SERBIA . . . . . . . .1669

26. Vladimir Zakić, Vlado Kovačević, Jelena Damnjanović SIGNIFICANCE OF FINACIAL LITERACY FOR THE AGRICULTURAL HOLDINGS IN SERBIA . . . . . . . . . . 1687

27. Željko Bjelajac, Marijana Dukić Mijatović, Željko Vojinović PROTECTION OF LAND IN THE REPUBLIC OF SERBIA AND ECOLOGICAL SECURITY WITH REGARD TO STRATEGIC AND LEGAL FRAMEWORKS . . . . . . . . . .1703 